\title{
Utility of Methylene Blue Guided Limberg Flap on Long- term Recurrence in Adult Chronic Pilonidal Disease
}

\section{Erişkin Kronik Pilonidal Sinüs Hastalığında Metilen Mavisi Kılavuzluğunda Uygulanmış Limberg Flepli Hastaların Uzun Dönem Nüks Açısından Değerlendirilmesi}

\author{
(1) Adnan Kuvvetli, @ ( Süleyman Çetinkunar, @ Alper Parlakgümüş \\ Adana City Training and Research Hospital, Clinic of General Surgery, Adana, Turkey
}

\section{HIIIIII| ABSTRACT}

Aim: Pilonidal sinus is a chronic intermittent disease, usually involving the sacrococcygeal area. This study was undertaken to compare the long-term results of peroperative methylene blue use in patients with pilonidal disease who underwent Limberg flap technique with and without methylene blue application.

Method: Patients who underwent Limberg flap for pilonidal sinus surgery between January 2014 and November 2018 were divided into two groups: methylene blue-guided surgery (group 1) and unguided surgery (group 2). Data of the patients were collected from the files, and the long-term recurrence data of the patients were obtained by one-to-one phone calls and outpatient controls at 36 months. Age and body mass index (BMI) were also evaluated. BMI of the patients was categorized as $18.1-20.0 \mathrm{~kg} / \mathrm{m}^{2}, 20.1-22.5 \mathrm{~kg} / \mathrm{m}^{2}, 22.6-25.0 \mathrm{~kg} / \mathrm{m}^{2}, 25.1-27.5 \mathrm{~kg} / \mathrm{m}^{2}, 27.6-30.0 \mathrm{~kg} / \mathrm{m}^{2}$ and $>30.1$ $\mathrm{kg} / \mathrm{m}^{2}$.

Results: Methylene blue was performed in 62 of 100 patients who underwent Limberg flap procedure and there was one recurrence in both groups. Methylene blue application did not have an effect on long-term recurrence ( $\mathrm{p}=0.98)$. BMI groups and recurrence were analyzed regardless of methylene blue use, and BMI greater than $27.5-30.0 \mathrm{~kg} / \mathrm{m}^{2}$ was statistically significant in the development of recurrence in long-term results ( $\mathrm{p}=0.040$ ).

Conclusion: Although it is considered as an integral part of pilonidal sinus surgery, there is no superiority of methylene blue guided surgery on longterm recurrences.

Keywords: Pilonidal disease, Limberg flap, methylene blue, long-term

\section{|||||||||| ÖZ}

Amaç: Pilonidal sinüs aralıklı olarak iyileșen ve genellikle sakrokoksigeal alanı tutan kronik bir hastalıktır. Bu çalışma, pilonidal hastalığı bulunan ve ameliyat esnasında metilen mavisinin kulanıldığı ve kullanılmadığı Limberg flep uygulanmış hastalardaki uzun dönem sonuçlarını karşılaştırmak için yürütülmüştür.

Yöntem: Pilonidal sinüs nedeniyle Ocak 2014- Kasım 2018 arası Limberg flep uygulanmış olan hastalar metilen kılavuzluğunda cerrahi uygulanmış (grup 1) ve uygulanmamış (grup 2) olarak ayrıldılar. Hasta bilgileri dosyalarda edinilip, uzun dönem nüksler hastalıklarının 36. ayında bire bir telefon görüşmeleri ve poliklinik kontrolleri ile sağlandı. Yaş, beden kitle indeksi (BKi) ayrıca takip edildi. BKİ, 18,1-20,0 kg/m², 20,1-22,5 kg/m², 22,6-25,0 $\mathrm{kg} / \mathrm{m}^{2}, 25,1-27,5 \mathrm{~kg} / \mathrm{m}^{2}, 27,6-30,0 \mathrm{~kg} / \mathrm{m}^{2}$ and $>30,1 \mathrm{~kg} / \mathrm{m}^{2}$ olarak katogorize edildi.

Bulgular: Limberg flep uygulanmış olan 100 hastadan 62'sine metilen mavisi uygulanmış olup, her iki grupta da birer nüks olgusu mevcuttu. Uzun dönem nükslerde metilen mavisi kılavuzluğunda cerrahinin nükse etkisi görülmedi ( $\mathrm{p}=0,98)$. BKİ ve nüks arasında metilen mavisi kullanımından bağımsız olarak yapılan incelemede, BKİ'nin $27,5-30,0 \mathrm{~kg} / \mathrm{m}^{2}$ den büyük olduğu kişilerde nüks gelişiminin istatiksel olarak daha fazla olduğu görüldü $(\mathrm{p}=0,040)$.

Sonuç: Pilonidal sinüs cerrahisinin ayrılmaz bir parçası olarak düşünülse de uzun dönem nüksler üzerinde metilen mavisi kılavuzluğunda yapılan cerrahilerin herhangi bir üstünlüğü yoktur.

Anahtar Kelimeler: Pilonidal hastalık, Limberg flep, metilen mavisi, uzun dönem 


\section{Introduction}

Pilonidal sinus is a chronic intermittent disease that usually involves the sacrococcygeal area and commonly affects young and middle-aged male patients. ${ }^{1}$ There are several techniques described for the treatment of this disease and Limberg flap is one of the most preferred techniques because of its low complication rate and acceptable longterm results. ${ }^{2}$ There are disagreements on the utility of methylene blue-guided surgery in sacrococcygeal pilonidal sinus disease. In this study, we retrospectively evaluated 100 patients who were operated using Limberg flap technique with and without methylene blue in order to determine the effectiveness of methylene blue in long-term results.

\section{Materials and Methods}

This study was approved by the local ethics committee (approval no: 326). The patients who underwent Limberg flap for pilonidal sinus surgery between January 2014 and November 2018 were evaluated. The patients were divided into two groups as patients managed by methylene blueguided surgery (group 1) and unguided surgery (group 2). The data of the patients were collected from the files, and the recurrences of the patients were followed-up with one-to-one phone calls and outpatient clinic controls after telecommunications at $36^{\text {th }}$ month. Age and body mass index (BMI) were also evaluated. BMI of the patients was categorized as $18.1-20.0 \mathrm{~kg} / \mathrm{m}^{2}, 20.1-22.5 \mathrm{~kg} / \mathrm{m}^{2}, 22.6-25.0$ $\mathrm{kg} / \mathrm{m}^{2}, 25.1-27.5 \mathrm{~kg} / \mathrm{m}^{2}, 27.6-30.0 \mathrm{~kg} / \mathrm{m}^{2}$ and $>30.1 \mathrm{~kg} /$ $\mathrm{m}^{2}$. Since the aim of the study was to evaluate the longterm results of the patients, early clinical conditions and complications were overlooked and not followed-up. The patients with missing data, patients with acute pilonidal disease and patients younger than 18 years were excluded.

\section{Statistical Analysis}

The data analysis was performed using SPSS for Windows, version 22 (SPSS, Chicago, IL, USA). The normality of the distribution of continuous variables was determined by Kolmogorov-Smirnov test. The data were reported as mean \pm standard deviation for parametric tests or as median and range for non-parametric tests, where applicable. The differences between the data from the groups were compared with Student's t-test or One-way ANOVA test, where appropriate. The categorical data were analyzed using Pearson's chi-square or Fisher's exact test, where appropriate. Multiple logistic regression analysis was used to assess the differences between groups in terms of age, gender, BMI and methylene blue. A p value less than 0.05 was considered statistically significant.

\section{Results}

Eighty-six patients were excluded due to inability to make contact or missing data. The remaining 100 patients who underwent Limberg flap reconstruction were divided as patients managed by methylene blue-guided surgery (group 1) and unguided patients (group 2). Demographic variables are shown in Table 1. Methylene blue was applied to 62 patients. There were 2 recurrences (2\%) and were equally distributed in group 1 and group 2, indicating that methylene blue application had no effect on long-term recurrence outcomes $(\mathrm{p}=0.98)$. These two patients with recurrences had a BMI over $27.5 \mathrm{~kg} / \mathrm{m}^{2}$. BMI groups and recurrence were analyzed regardless of methylene blue use, and BMI greater than $27.5-30.0 \mathrm{~kg} / \mathrm{m}^{2}$ was statistically significant in the development of recurrence in long-term results $(\mathrm{p}=0.040)$.

\section{Discussion}

Pilonidal sinus disease is a common surgical disease that mostly involves the young population. There are several treatment modalities, including simple incision and drainage, deroofing, marsupialization, excision and primary closure or rhomboid excision with Limberg flap procedure. ${ }^{3}$ Unfortunately, none of the existing surgical options is perfect. The ideal treatment should eradicate the disease, minimize the risk of recurrence, and be associated with low morbidity and short recovery time. Many studies have reported a recurrence rate of $7-42 \%$ following excision and primary closure; however, a recurrence rate of approximately $3 \%$ was reported following Limberg flap repair. ${ }^{2}$ Other authors also advocate the benefits of this technique as being effective with a low complication rate, shorter time to return to normal activity, and shorter hospitalization. ${ }^{4}$ In order to standardize the long-term results of this study, we preferred to evaluate the patients operated with this technique due to its low rate of recurrence. Methylene blue-guided surgery is

Table 1. Demographic variables according to body mass index distribution and age

$\begin{array}{lll}\text { Age, years } & & 25 \text { (18-67) } \\ \text { Male/female ratio } & & 9 / 1 \\ & 18.1-20.0 \mathrm{~kg} / \mathrm{m}^{2} & 2 \\ & 20.1-22.5 \mathrm{~kg} / \mathrm{m}^{2} & 23 \\ & 22.6-25.0 \mathrm{~kg} / \mathrm{m}^{2} & 26 \\ \text { BMI groups (n) } & 25.1-27.5 \mathrm{~kg} / \mathrm{m}^{2} & 25 \\ & 27.6-30.0 \mathrm{~kg} / \mathrm{m}^{2} & 12 \\ & >30.1 \mathrm{~kg} / \mathrm{m}^{2} & 12\end{array}$

BMI: Body mass index 
the most adopted and preferred technique for the treatment of pilonidal disease. ${ }^{5}$ Many surgeons use the dye in order to prevent recurrence due to inadequate excision. There are opponents of this approach advocating unreliableness of methylene blue to help with adequate excision. Doll et al. ${ }^{6}$ followed up the patients who were operated for chronic pilonidal disease with and without methylene blue guidance. The recurrence rates after a mean of 14.9 years were 19\% in patients operated with methylene blue guidance and $24 \%$ among those without methylene blue ( $\mathrm{p}=0.35)$. These results are convincing the unreliableness of methylene blue to prevent recurrence of the disease in chronic pilonidal disease. In acute pilonidal disease, methylene blue was found to be useful in preventing recurrences. ${ }^{6}$ Idiz et al. ${ }^{5}$ evaluated the specimens excised with and without the guidance of methylene blue with microscopic assessment parameters, and found that the application of methylene blue in pilonidal disease surgery may cause inadequate excision of the diseased area. These two results give the same opinion as the findings in our study.

In conclusion, although we consider it as an integral part of pilonidal sinus surgery, methylene blue-guided surgery has no benefit on the long-term recurrence rates of chronic disease.

\section{Ethics}

Ethics Commitee Approval: The study was approved by the Adana City Training and Research Hospital Ethics Committee (project no: 326).
Informed Consent: Informed consent was obtained from all individual participants included in the study.

Peer-review: Internally peer-reviewed.

\section{Authorship Contributions}

Surgical and Medical Practices: A.P., Concept: A.K., Design: S.Ç., Data Collection or Processing: A.K., Analysis or Interpretation: S.Ç., Literature Search: A.P., Writing: A.P.

Conflict of Interest: No conflict of interest was declared by the authors.

Financial Disclosure: The authors declared that this study received no financial support.

\section{References}

1. Keighley MRB. Pilonidal disease. In: Keigjhey MRB, Williams NS, eds. Surgery of anus, rectum and colon. London: W.B. Saunders; 1993:467489 .

2. Akca T, Colak T, Ustunso B, Kanik A, Aydin S. Randomized clinical trial comparing primary closure with the Limberg flap in the treatment of primary sacrococcygeal pilonidal disease. Brit J Surg 2005;92:1081-1084.

3. Al-Hassan HK, Francis IM, Neglen P. Primary closure or secondary granulation after excision of pilonidal sinus. Acta Chir Scand 1990;156:695699.

4. Akin M, Gokbayir H, Kilic K, Topgul K, Ozdemir E, Ferahkose Z. Rhomboid excision and Limberg flap for managing pilonidal sinus: long-term results in 411 patients. Colorectal Dis 2008;10:945-948.

5. Idiz UO, Aysan E, Firat D, Bozkurt S, Buyukpinarbasili N, Muslumanoglu M. Int J Clin Exp Med 2014;7:927-931.

6. Doll D, Novotny A, Rothe R, Kristiansen JE, Wietelmann K, Boulesteix AL, Düsel W, Petersen S. Methylene Blue halves the long-term recurrence rate in acute pilonidal sinus disease. Int J Colorectal Dis 2008;23:181-187. 